\title{
ZMIANA W KOŚCIELE
}

\section{ROZMOWA O KSIĄŻCE MICHAŁA ROGALSKIEGO \\ PRODUCENCI MARGARYNY? MARIAN ZDZIECHOWSKI \\ I POLSKI MODERNIZM KATOLICKI \\ RELACJA ZE SPOTKANIA AUTORSKIEGO}

Filip Lapiński

Uniwersytet Warszawski

8 kwietnia 2019 roku w księgarni „Tarabuk” odbyło się spotkanie autorskie poświęcone książce dr. Michała Rogalskiego Producenci margaryny? Marian Zdziechowski i polski modernizm katolicki. Autor jest historykiem filozofii oraz reżyserem teatralnym. Ponadto w dyskusji uczestniczył Tomasz Herbich, redaktor „Teologii Politycznej”, teolog, filozof i politolog. Spotkanie moderowała dr Dominika Michalak ${ }^{1}$.

Rogalski rozpoczął od wyjaśnienia sensu tytułowej metafory: ,producenci margaryny". Odwołanie to zaczerpnięte jest z kazania XIX-wiecznego biskupa Paula Wilhelma von Kepplera, który, potępiając modernizm religijny, nazwał go „katolicyzmem margarynowym”. Przekonywał, że nurt ten ma charakter fałszywy, sztuczny oraz zagrażający tradycji i nauczaniu Kościoła. To plastyczne określenie stało się dobrym punktem do zarysowania szerszego problemu palących napięć między tradycjonalistyczną a modernistyczną interpretacją chrześcijaństwa. Podstawowym zagadnieniem modernizmu jako szeroko ujętej orientacji w myśli religijnej z przełomu XIX i XX wieku było pytanie o właściwy stosunek Kościoła rzymskokato-

1 Niestety, z powodu choroby swoją obecność na spotkaniu odwołała Zuzanna Radzik. 
lickiego do współczesnego świata, przez który rozumiano przede wszystkim rzeczywistość dokonujących się zmian kulturowych, społecznych czy technologicznych. Pytania o słuszność korzystania z rosnącego dorobku nowoczesności domagały się odpowiedzi - moderniści uważali, że należy z życzliwą otwartością wyjść naprzeciw przemianom społecznym i politycznym. Zmieniające się doświadczenia współczesnego człowieka potrzebowały interpretacji, która nie skazałaby go wraz z cała nowoczesnością na wykluczenie z wciąż przednowoczesnego Kościoła.

Jednak, jak podkreślał Rogalski, trudny dla Kościoła wiek XIX nie sprzyjał takiej optymistycznej reorientacji, tym bardziej że kwestie odnoszące się do reformy dotyczyć musiały najgłębszej tożsamości katolicyzmu. Podstawowym źródłem i sensem wiary religijnej jest bowiem to, iż jej treść pochodzi z Bożego objawienia i w związku z tym nie podlega dowolnemu modyfikowaniu przez człowieka. Problem jest tak trudny, że sama próba opisania go grozi opowiedzeniem się za którąs ze stron sporu. Gdzie $\mathrm{w}$ takim razie istnieje miejsce na zmianę w katolicyzmie? Potrzeba podkreślania ciagłości i jedności historycznego doświadczenia Kościoła utrudnia reinterpretację tradycji, lecz w przekonaniu autora książki zaprezentowane przez Mariana Zdziechowskiego rozumienie katolicyzmu daje możliwość przezwyciężenia tej trudności.

Tomasz Herbich podkreślał, iż za podstawową tezę książki Rogalskiego uznaje, że polski modernizm katolicki istniał - a sprawa ta nie była wcale oczywista, biorąc pod uwagę to, jak często jego istnienie było negowane w polskiej literaturze przedmiotu. Argumentacja zawarta w książce i oparta na rzetelnym studium materiałów źródłowych zdaje się pokazywać, iż mówienie o polskiej wersji tego ruchu intelektualnego jest jednak zasadne. Kluczowym atutem książki dla Herbicha jest nowy sposób interpretowania pism Zdziechowskiego - postaci kluczowej dla polskiego modernizmu katolickiego. W książce opisano efekt analizy i interpretacji głównej pracy filozofa Pesymizm, romantyzm a podstawy chrześsijaństwa jako sposobu badania źródeł i współczesności nowych modernistycznych nurtów myśli katolickiej, sam zaś pesymizm uznano za kategorię drugorzędną bez głębszego znaczenia filozoficznego. „Pesymizm” to jedynie nazwa stosunku Zdziechowskiego wobec człowieka obecnego w świecie - zagadnienia, które przykuwało jego uwagę od początku drogi intelektualnej filozofa. Dla Zdziechowskiego, podążającego śladami François-René Chateaubrianda, problem zła ma paradoksalnie bronić chrześcijaństwa, co też w książce Rogalskiego przenikliwie i szeroko opisano. To wiara stać się może wyrazem egzystencjalnego sprzeciwu wobec obecnych w świecie cierpień i aktów zła. 
Herbich zgodził się również na uznanie wagi sporu między modernistami a tradycjonalistami. Zadanie pytania o uznanie (lub odrzucenie) doświadczeń nowoczesnego podmiotu w ramach katolickiej myśli religijnej tworzy niesłychanie skomplikowany spór, który na soborze watykańskim II został częściowo rozwiązany przez próbę stworzenia syntezy obydwu podejść. Herbich podkreślił także, iż wnioski Rogalskiego pozwalają zastanowić się nad współczesną Polską i zlokalizować kontynuatorów modernizmu w dzisiejszym polskim Kościele, np. w środowiskach „Więzi” czy „Tygodnika Powszechnego”. Co dla publicysty „Teologii Politycznej” stanowi pozytywną wartość wnoszoną przez modernistów katolickich, to praca nad stworzeniem uniwersalnej moralności opartej na chrześcijaństwie i zgodnej z potrzebami współczesnego człowieka.

W trakcie spotkania omawiane były także historyczne losy modernizmu katolickiego. Ów nurt, potępiony przez papieża Piusa X (encyklika Pascendi dominici gregis), dość szybko został zneutralizowany jako ruch i reprezentujące go środowisko. Pod groźba surowych kar kościelnych (z ekskomuniką włącznie) wielu reformistycznych filozofów odwoływało swoje poglądy bądź kończyło poza nawiasem katolickiego życia religijnego. Podobny los spotkał Zdziechowskiego, który publicznie odżegnał się od własnych tez (choć w świetle jego dorobku filozoficznego szczerość tego odwołania jest kwestią dyskusyjną). Uczniowie wielkich modernistów, chcąc kontynuować dzieło mistrzów, kultywowali pomimo obostrzeń ich wrażliwość za parawanem niuansów i pozornych rozróżnień.

Inną sprawą poruszoną w książce jest z kolei zmiana, która zaszła w samym Zdziechowskim w wyniku śmierci syna, tragedii I wojny światowej i rewolucji komunistycznej. Od tego czasu niedawny myśliciel modernistyczny przesuwał się na pozycje konserwatywne, głęboko antykomunistyczne i mistycyzujące. Jego myśl jednak, tak jak na początku kariery naukowej, krążyła wciąż wokół problemu zła.

Przedmiotem dyskusji z publicznością były m.in. rola zbawienia u modernistów (które pojawia się u nich raczej implicite), możliwe podobieństwo późnego Zdziechowskiego do konserwatywnego i prokatolickiego, lecz jednocześnie niewierzącego prof. Bogusława Wolniewicza, miejsce na konserwatywno-mistyczne oblicze Zdziechowskiego w Producentach margaryny czy wreszcie różnorodność współczesnego polskiego katolicyzmu.

Do sprawozdania o książce dołączamy także recenzję książki Rogalskiego przygotowaną przez Tomasza Herbicha. 